\title{
A green protocol for the synthesis of bis(indolyl)methanes catalyzed by succinic acid under microwave irradiation
}

\author{
Aayesha Nasreen $^{1 *}$, Ravi Varala ${ }^{2}$ and Kulakarni Sripad Rao ${ }^{2}$ \\ ${ }^{1}$ Department of Chemistry, College of Science (Girls), Jazan University, 6811-Arroudah \\ P.O. Box No. 2097, Jazan 82724-3750, Saudi Arabia \\ ${ }^{2}$ Departmet of Chemistry, RGUKT Basar, Nirmal-504107, Telangana, India
}

(Received October 13, 2016; Revised January 4, 2017; Accepted January 31, 2017)

\begin{abstract}
An eco-friendly simple and efficient synthesis of 3,3'-bis(indolyl)methanes was carried out by electrophilic substitution reaction of indole with structurally divergent aldehydes by using succinic acid as green catalyst and water as green solvent under microwave irradiation. The advantages of this protocol are excellent yields, higher availability, inexpensive catalyst, lack of toxicity, shorter reaction time and more environmentally friendly catalyst. The reaction is chemoselective applicable only to aldehydes.
\end{abstract}

Keywords: Indole; aldehydes; succinic acid; water; bis(indolyl)methanes; microwave irradiation. (C) 2017 ACG Publications. All rights reserved.

\section{Introduction}

Indole frame work is featured in a wide variety of pharmacologically and biologically active compounds occurred in nature. ${ }^{1}$ For example, bis(indolyl)methanes are found in cruciferous plants such as brococoli, ${ }^{2}$ bioactive metabolites of terrestrial and marine origin e.g. vibrindole-A. ${ }^{3}$ Bis(indolyl)methanes are known to promote beneficial estrogen metabolism and induce apoptosis in human cancer cell. ${ }^{4 a, b}$ Other beneficial activities such as dietary supplements, ${ }^{5}$ topoisomerase IIa inhibitors, ${ }^{6}$ antibacterials, ${ }^{7}$ antibiotics,${ }^{8}$ antifungal, ${ }^{9}$ anti-inflammatory ${ }^{10}$ antimicrobialactivities, ${ }^{11}$ agrochemicals, ${ }^{12}$ and in material sciences as calorimetric sensors, particularly for various metals and fluorides. ${ }^{13 a, b}$

Due to their broad range of biological applications, there is a great deal of interest in the synthesis of bis(indolyl)methane derivatives. Synthetically these compounds are obtained from the electrophilic substitution at 3-position of indoles with aldehydes and ketones. Over the past few years syntheses of this class of molecules under different conditions have been reported with promoters such as $\mathrm{KHSO}_{4}-\mathrm{SiO}_{2}{ }^{14-29}$ NBS, ${ }^{30} \quad \mathrm{P}_{2} \mathrm{O}_{5} / \mathrm{SiO}_{2},{ }^{31} \quad \mathrm{NanoSiO}_{2}$-Ultrasonicirradiation, ${ }^{32}$ [Bmim]Br/microwave, ${ }^{33}$ Zeokarb-225, ${ }^{34}$ [n-

\footnotetext{
*Corresponding author: E-Mail: aayesha_iict@yahoo.co.in
} 
$\left.\mathrm{Pr}_{2} \mathrm{NH}_{2}\right]\left[\mathrm{HSO}_{4}\right] . \mathrm{IL},{ }^{35} \mathrm{PPh}_{3} \cdot \mathrm{HClO}_{4}{ }^{36}$ Oxalic acid, ${ }^{37}$ 12-TPA, $\mathrm{H}_{3} \mathrm{PW}_{12} \mathrm{O}_{40},{ }^{38}$ Silicagel, ${ }^{39}$ Glycerin$\mathrm{CeCl}_{3} .7 \mathrm{H}_{2} \mathrm{O},{ }^{40} \mathrm{BF}_{3} . \mathrm{Et}_{2} \mathrm{O},{ }^{41}$ Citric acid, ${ }^{42} \mathrm{PPh}_{3} \mathrm{CCl},{ }^{43}$ Choline Chloride/Urea ${ }^{44}$

However, most of these reported methods deal with toxic materials and solvents, high cost, long reaction time and burdensome work up procedures. Keeping in view of the tremendous importance of bis(indolyl)methanes there emerge a consistent demand of developing reaction conditions possessing readily available nontoxic materials, shorter reaction time, and green solvents as environmentally benign substitutes in this area.

Microwave assisted organic synthesis (MAOS) has emerged as a new "lead" in organic synthesis. Organic chemists are concerned in the development of green procedures by using microwave irradiation under solvent free conditions or in water as a green solvent. Important advantage of this technology include highly accelerated rate of the reaction, reduction in reaction time with an improvement in the yield and quality of the product. ${ }^{45 a-f}$

Making use of simply available and biodegradable catalyst for organic conversion has been achieving enormous significance in the last few years due to their operational simplicity, low cost, ease of preparation and handling, stability, lack of toxicity, environmental friendly, more importantly the fact that the efficiency and selectivity of these reagents meet the standards of established organic reactions. In this regard, succinic acid works as performing the role of perfect catalyst. Succinic acid is a common metabolite in plants, animals and microorganisms and has been used widely in the agricultural, pharmaceutical and industrial applications such as, resins, polymer, paints, cosmetics and inks. Succinic acid is widely used as an organo-catalyst because it is nontoxic, cheap, safe to handle, and easily biodegradable. ${ }^{46 a-f}$

In continuation of our research and interest in the development of new highly expedient protocols $^{47 a-d}$ for the synthesis of fine chemicals and heterocyclic compounds of biological importance, we report here the synthesis of bis(indolyl)methanes from the condensation of various aldehydes with indole in the presence of succinic acid as organic catalyst and water as green solvent under microwave irradiation (Scheme1).

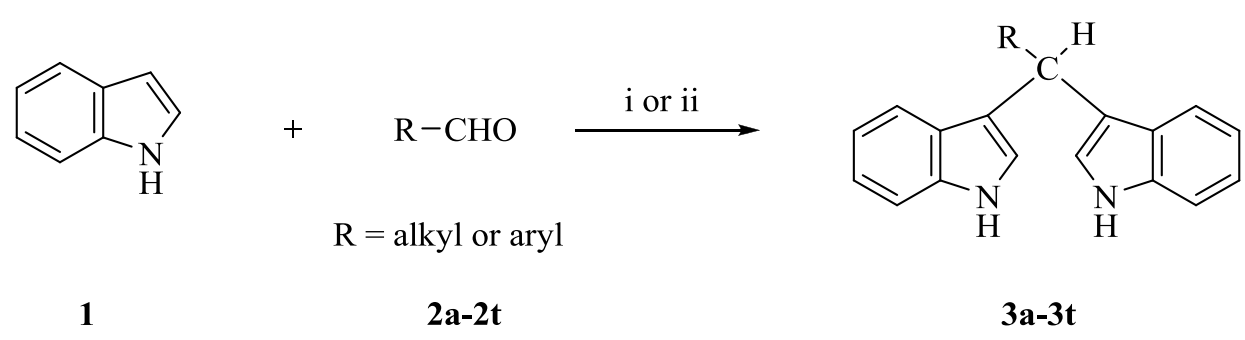

Scheme 1. Reagents and reaction conditions: Synthesis of bis(indolyl)methanes (3a-3t) from indole (1) and aldehydes (2a-2t) under conditions: i) succinic acid $(10 \mathrm{~mol} \%) / \mathrm{H}_{2} \mathrm{O}$; ii) microwave irradiation/9-15 minutes

\section{Experimental}

Melting points were determined on Perfit Melting Temperature apparatus and are uncorrected. The IR spectra were obtained by using Thermo Nicolet Nexus 670 FT-IR spectrometer in KBr pellets. Panasonic company microwave $(2450 \mathrm{MHz}$ frequency at a power output of $1000 \mathrm{~W})$ was used for the microwave irradiation. The ${ }^{1} \mathrm{H}$ NMR and ${ }^{13} \mathrm{C}$ spectra were recorded on Avance $300 \mathrm{MHz}$ spectrometer in DMSO using tetramethylsilane (TMS) as internal reference. All chemical shifts $(\delta)$ were reported in ppm from internal TMS. MS were recorded on Finnegan MAT 1020 Mass spectrometer operating at $70 \mathrm{eV}$. The hydrazonoyl halides $\mathbf{1}^{12-15}$ and methylhydrazones $\mathbf{3}^{9,16}$ were prepared according to known literature procedures. 


\subsection{General procedure for synthesis of bis(indolyl)methanes (3a-t):}

A mixture of indole (1) $(2 \mathrm{mmol})$, aldehydes (2a-t) $(1 \mathrm{mmol})$ and water $(5 \mathrm{~mL})$ succinic acid $(10$ mol\%) was irradiated with microwave $(300 \mathrm{~W}$ ) for varying period of time as indicated in (Table3). After completion of the reaction as indicated by TLC, the reaction mixture was filtered and washed with water and recrystallized using ethanol to obtain the corresponding bis(indolyl)methanes (3a-t). All the products were well characterized by ${ }^{1} \mathrm{H}-\mathrm{NMR}$, mass spectral analysis and were found to be identical with those reported in the literature. ${ }^{14,17,35,38,44}$.

The following compounds were synthesized using this method:

3,3'-bisindolyl(phenyl)methane (3a) (Table 3 entry 1): Yield: $96 \% ;{ }^{1} \mathrm{H}$ NMR (DMSO) ( $\left.\delta / \mathrm{ppm}\right): 7.88$ (brs, 2H), 7.41-7.14 (m, 11H), $7.01(\mathrm{t}, 2 \mathrm{H}, J=6.9 \mathrm{~Hz}), 6.65(\mathrm{~s}, 2 \mathrm{H}), 5.90(\mathrm{~s}, 1 \mathrm{H}) ;{ }^{13} \mathrm{C}$ NMR (DMSO)

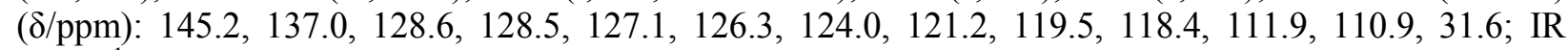
$\left(\mathrm{v} / \mathrm{cm}^{-1}\right): 3406,3059,3028,1721,1596,1460,1416,1337,1240,1099,1014,747,700 ;$ MS (EI): $\mathrm{m} / \mathrm{z}$ : $322\left[\mathrm{M}^{+}\right]$; Anal. Calcd for $\mathrm{C}_{23} \mathrm{H}_{18} \mathrm{~N}_{2}: \mathrm{C}, 85.68 ; \mathrm{H}, 5.63 ; \mathrm{N}, 8.69$. Found $\mathrm{C}, 85.61 ; \mathrm{H}, 5.54 ; \mathrm{N}, 8.62$.

3,3'-((4-methylphenyl)methylene)bis(1H-indole) (3b) (Table 3 entry 2): Yield: 95\%; ${ }^{1} \mathrm{H}$ NMR (DMSO) ( $\delta / \mathrm{ppm}): 7.86$ (brs, 2H), 7.39 (d, 2H, $J=7.79 \mathrm{~Hz}), 7.33$ (d, 2H, $J=8.04 \mathrm{~Hz}), 7.24-6.95(\mathrm{~m}, 8 \mathrm{H})$, $6.62(\mathrm{dd}, 2 \mathrm{H}, J=2.22,0.9 \mathrm{~Hz}), 5.84(\mathrm{~s}, 1 \mathrm{H}), 2.31(\mathrm{~s}, 3 \mathrm{H}) ;{ }^{13} \mathrm{C}$ NMR (DMSO) $(\delta / \mathrm{ppm}): 141.1,136.8$, 135.4, 128.9, 128.6, 127.2, 123.5, 121.8, 119.9, 119.9, 119.1, 111.0, 39.9, 21.0; IR (v/cm $\left.\mathrm{cm}^{-1}\right): 3409,2917$, 2855, 1708, 1657, 1412, 745; MS (EI): $m / z: 336\left[\mathrm{M}^{+}\right]$; Anal. Calcd for $\mathrm{C}_{24} \mathrm{H}_{20} \mathrm{~N}_{2}: \mathrm{C}, 85.68 ; \mathrm{H}, 5.99$; N, 8.33. Found C, 85.61; H, 5.93; N, 7.24.

3,3'-((4-methoxyphenyl)methylene)bis(1H-indole) (3c) (Table 3 entry 3): Yield: 95\%; ${ }^{1} \mathrm{H}$ NMR

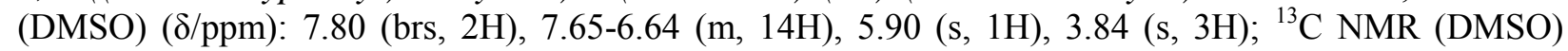

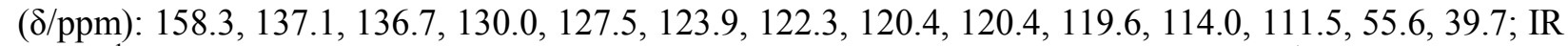
$\left(v / \mathrm{cm}^{-1}\right): 3396,2945,1597,1510,1459,1258,1256,1004,739 ; \mathrm{MS}(\mathrm{EI}): \mathrm{m} / z: 352$ [M ${ }^{+}$; Anal. Calcd for $\mathrm{C}_{24} \mathrm{H}_{20} \mathrm{~N}_{2} \mathrm{O}: \mathrm{C}, 81.79 ; \mathrm{H}, 5.72 ; \mathrm{N}, 7.95$. Found C, 81.71; H, 5.67; N, 7.88.

3,3'-((4-nitrophenyl)methylene)bis(1H-indole) (3f) (Table 3 entry 6): Yield: 94\%; ${ }^{1} \mathrm{H}$ NMR (DMSO) $(\delta / \mathrm{ppm}): 8.19$ (brs, 2H, NH), 8.05 (d, 2H, $J=8.6 \mathrm{~Hz}), 7.50$ (d, 2H, $J=8.6 \mathrm{~Hz}), 7.40-7.12$ (m,

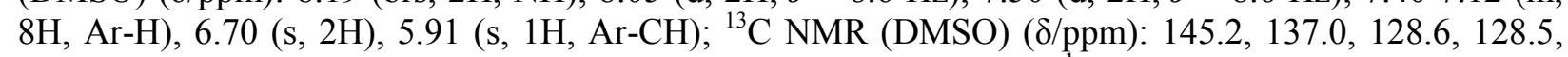
127.1, 126.3 124.0, 121.2, 119.5, 118.4, 111.9, 110.9, 31.6; IR $\left(\mathrm{v} / \mathrm{cm}^{-1}\right): 3429,3055,1599,1519,1457$, 1359; MS (EI): $m / z: 367$ [M ]; Anal. Calcd for $\mathrm{C}_{23} \mathrm{H}_{17} \mathrm{~N}_{3} \mathrm{O}_{2}: \mathrm{C}, 75.19 ; \mathrm{H}, 4.66 ; \mathrm{N}, 11.44$. Found C, 75.12; $\mathrm{H}, 4.59 ; \mathrm{N}, 11.37$.

3,3'-((4-chlorophenyl)methylene)bis(1H-indole) (3h) (Table 3 entry 8): Yield: 92\%; ${ }^{1} \mathrm{H}$ NMR (DMSO) (8/ppm): 7.95 (brs, 2H, NH), 7.35-7.25 (m, 8H, Ar-H), 7.15 (d, 2H, J 7.9 Hz), 7.05 (d, 2H, J= $8.3 \mathrm{~Hz}), 6.65$ (s, 2H), 5.80 (s, 1H, Ar-CH); ${ }^{13} \mathrm{C}$ NMR (DMSO) (d/ppm): 146.3, 136.8, 134.2, 129.7, 129.0, 127.0, 126.6, 123.8, 122.3, 120.0, 119.6, 119.1, 111.3, 40.2; IR (v/ $\left.\mathrm{cm}^{-1}\right): 3420,3054,1499,1460,1093$; MS (EI): $m / z$ : $356\left[\mathrm{M}^{+}\right]$; Anal. Calcd for $\mathrm{C}_{23} \mathrm{H}_{17} \mathrm{ClN}_{2}$ : C, 77.41; H, 4.80; Cl, 9.93; N, 7.85. Found C, 77.34; H, 4.73; N, 7.78.

3,3'-((4-cyanophenyl)methylene)bis(1H-indole) (3n) (Table 3 entry 14): Yield: 92\%; ${ }^{1} \mathrm{H}$ NMR (DMSO) $(\delta / \mathrm{ppm}): 8.04(\mathrm{br}, 2 \mathrm{H}), 7.56(\mathrm{~d}, 2 \mathrm{H}, J=8.4 \mathrm{~Hz}), 7.43(\mathrm{~d}, 2 \mathrm{H}, J=8.2 \mathrm{~Hz}), 7.34-7.01(\mathrm{~m}, 8 \mathrm{H})$, $6.63(\mathrm{~s}, 2 \mathrm{H}), 5.93(\mathrm{~s}, 1 \mathrm{H}) ;{ }^{13} \mathrm{C}$ NMR (DMSO) (8/ppm): 149.8, 136.7, 132.1, 129.3, 126.8, 123.7, 122.3, 119.5, 119.2, 119.2, 118.1, 111.3, 109.9, 40.3; IR (v/cm $\left.{ }^{-1}\right): 3396,2229,1735,1658,1363,1215,1099$, 745; MS (EI): $m / z: 347\left[\mathrm{M}^{+}\right]$; Anal. Calcd for $\mathrm{C}_{24} \mathrm{H}_{17} \mathrm{~N}_{3}$ : C, 82.97; H, 4.93; N, 12.10. Found C, 82.61; H, $4.54 ; \mathrm{N}, 11.82$.

3,3'-((3-pyridyl)methylene)bis(1H-indole) (3o) (Table 3 entry 15): Yield: 85\%; ${ }^{1} \mathrm{H}$ NMR (DMSO)

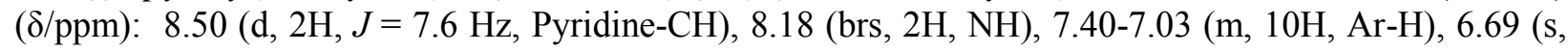


2H, Ar-H), 5.89 (s, 1H, Ar-CH); ${ }^{13} \mathrm{C}$ NMR (DMSO) (8/ppm): 155.7, 137.8, 137.0, 133.7, 129.5, 128.6, $127.9,124.1,121.2,119.3,118.5,112.8,32.3 ; \mathrm{IR}\left(\mathrm{v} / \mathrm{cm}^{-1}\right): 3448,3029,2780,1677,1699,904,718 ; \mathrm{MS}$ (EI): $m / z: 322\left[\mathrm{M}^{+}\right]$; Anal. Calcd for $\mathrm{C}_{22} \mathrm{H}_{17} \mathrm{~N}_{3}: \mathrm{C}, 81.71 ; \mathrm{H}, 5.30 ; \mathrm{N}, 12.99$. Found $\mathrm{C}, 81.61 ; \mathrm{H}, 5.24 ; \mathrm{N}$, 12.62 .

3,3'-((thiophen-2-ylmethylene)bis(1H-indole) (3p) (Table 3 entry 16): Yield: $80 \%$; ${ }^{1} \mathrm{H}$ NMR

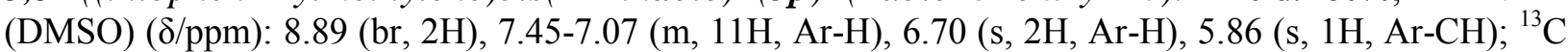

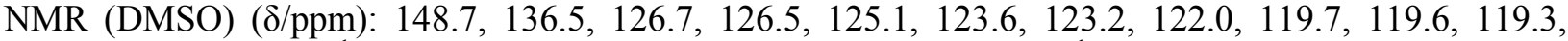
111.2, 35.3; IR $\left(v / \mathrm{cm}^{-1}\right): 3416,1735,1658,1356,1217,1080,750 \mathrm{~cm}^{-1}$; MS (EI): $\mathrm{m} / z: 328\left[\mathrm{M}^{+}\right]$; Anal. Calcd for $\mathrm{C}_{22} \mathrm{H}_{16} \mathrm{~N}_{2} \mathrm{~S}$ : C, 76.80; H, 4.91; N, 8.53. Found C, 76.81; H, 4.90; N, 8.52.

\section{Results and Discussion}

A model reaction was performed at room temperature for 6 hours and the corresponding 3,3'bis(indolyl)phenylmethane was obtained in poor yield (34\%). In the absence of catalyst, there is no product formed even after irradiating for 1 hour. While comparing the effect of various organic acids as catalysts, we found that succinic acid (Table 1 entry 5) yielded relatively higher amount of desired product with lower amount of the catalyst (10 mol\% as standard) when compared with other organic acids tested such as picric, tannic, glutaric, ascorbic (Table 1) in shorter reaction time. This promoted us to go ahead with succinic acid as the best catalyst for the preparation of divergent bis(indolyl)methanes.

Table 1. Comparison of various organic acids ( $10 \mathrm{~mol} \%)$ as catalyst on model reaction between indole (2 $\mathrm{mmol})$, benzaldehyde $(1 \mathrm{mmol})$ in water $(5 \mathrm{~mL})$ under microwave irradiation

\begin{tabular}{llll}
\hline Entry & Catalyst & M.W/Time (min) & Yield \% \\
\hline $\mathbf{1}$ & Picric scid & 27 & 68 \\
$\mathbf{2}$ & Tannic acid & 25 & 72 \\
$\mathbf{3}$ & Glutaric acid & 25 & 69 \\
$\mathbf{4}$ & Ascorbic acid & 24 & 70 \\
$\mathbf{5}$ & Succinic acid & 9 & 96 \\
\hline
\end{tabular}

The initial studies were focused on to optimize the reaction conditions for the synthesis of bis(indolyl)methanes by choosing benzaldehyde $(1 \mathrm{mmol})$, indole $(2 \mathrm{mmol})$, succinic acid $(5 \mathrm{~mol})$, water $(5 \mathrm{~mL})$ as model reaction under microwave $(300 \mathrm{~W})$ irradiation for 20 minutes to obtain the corresponding 3,3'-bis(indolyl)phenylmethane in $65 \%$ yield. In a search for higher yield we varied the amount of catalyst succinic acid at different molar quantities on model reaction and, satisfyingly maximum yield of the corresponding 3,3'-bis(indolyl)phenylmethane $(96 \%)$ was obtained with (10 mol\%) of the succinic acid (Table 2 entry 3 ). Under conventional conditions, when the same reaction mixture was refluxed for $24 \mathrm{~h}$, the corresponding product was obtained in $54 \%$ yield.

Now with the optimal conditions in hand, we set about expanding the scope of different aldehydes like aromatic, aliphatic and heteroaromatic as suitable substrates to condense with indole to synthesize different derivatives of bis(indolyl)methanes with good to excellent yields (Table 3). The nature of substituents on phenyl ring showed some effects on this conversion. In general electron deficient aldehydes such as nitro, $N, N$-dimethyl and so forth required longer reaction times to produce the corresponding bis(indolyl)methanes compared with those of their electron rich counter parts (Table 3 entries $2,3,5,7,8,9)$. Cinnamldehyde (Table 3 entry 11), $p$-hydroxybenzaldehyde also produced good yields without undergoing polymerization or isomerization. Heteroaromatic aldehydes, for example, pyridine-3- carboxaldehyde (Table 3 entry 15), thiophene-2-aldehyde (Table 3 entry 16), furfuraldehyde (Table 3 entry 17) reacted well without formation of any side products under the present reaction 
conditions giving the corresponding bis(indolyl)methanes in good yield. Fortunately, acetaldehyde, 2butyraldehyde, cyclohexanal gave the corresponding bis(indolyl)methanes in good yields (Table 3 entries $18,19,20)$. All the products were well characterized by ${ }^{1} \mathrm{H}-\mathrm{NMR}$, mass spectral analysis and found to be identical with those reported in the literature.

Table 2. Screening of catalyst succinic acid on model reaction between indole ( $2 \mathrm{mmol})$, benzaldehyde (1 $\mathrm{mmol})$ in water $(5 \mathrm{~mL})$ under microwave irradiation

\begin{tabular}{llll}
\hline Entry & Catalyst (mol\%) & M.W/Time (min) & Yield \% \\
\hline $\mathbf{1}$ & No catalyst & 40 & 0 \\
$\mathbf{2}$ & 5 & 20 & 65 \\
$\mathbf{3}$ & 10 & 9 & 96 \\
$\mathbf{4}$ & 15 & 9 & 96 \\
$\mathbf{5}$ & 20 & 8 & 96 \\
\hline
\end{tabular}<smiles>c1ccc2[nH]ccc2c1</smiles><smiles>CC(=O)c1ccccc1</smiles><smiles>O=Cc1ccccc1</smiles><smiles>CCCCCC(c1c[nH]c2ccccc12)c1c[nH]c2ccccc12</smiles>

Exclusive product<smiles>CCCCCCC(c1c[nH]c2ccccc12)c1c[nH]c2ccccc12</smiles>

Exclusive product<smiles>CCCCC(C)(c1c[nH]c2ccccc12)c1c[nH]c2ccccc12</smiles>

$0 \%$<smiles>c1ccc2c(C(c3c[nH]c4ccccc34)C3CCCCC3)c[nH]c2c1</smiles>

$0 \%$

Scheme 2. Reagents and reaction conditions: Chemoselective synthesis of the corresponding bis(indolyl)methanes from indole, benzaldehyde, acetophenone and cyclohexanone under conditions: i) succinic acid $(10 \mathrm{~mol} \%) / \mathrm{H}_{2} \mathrm{O} /$; ii) microwave irradiation/9-35 minutes

Similar attempts to form bis(indolyl)methanes from ketones, unfortunately, failed to afford any reaction and simply resulted in the recovery of starting material. Possible explanation could be the reactivity difference of aldehyde and ketone functional groups. Some experiments were made to study the efficacy of succinic acid catalyzed selective synthesis of corresponding bis(indolyl)methanes from ketones. For example, the reaction of a mixture of acetophenone $(1 \mathrm{mmol})$ and benzaldehyde $(1 \mathrm{mmol})$ with indole $(2 \mathrm{mmol})$ afforded the corresponding benzaldehyde derived bis(indolyl)methane exclusively, even after irradiation for 35 minutes. Likewise, the reaction of a mixture of benzaldehyde $(1 \mathrm{mmol})$ and cyclohexanone $(1 \mathrm{mmol})$ with indole $(2 \mathrm{mmol})$ also yielded the corresponding benzaldehyde condensed product chemoselectively (Scheme 2). As a result, it seems that the present condition is suitable for aldehydes only. 
Table 3. Succinic acid catalyzed synthesis of bis(indolyl)methanes (3a-t) from indole (1) and aldehydes/ketones (2a-t).

\begin{tabular}{|c|c|c|c|c|c|}
\hline Entry & Aldehyde (2a-2t) & Product $(3 a-3 t)^{a}$ & Time $(\min )^{b}$ & $\begin{array}{l}\text { Yield \% } \\
\text { point }\left({ }^{\mathrm{C}} \mathrm{C}\right)^{\mathrm{d}}\end{array}$ & Melting \\
\hline 1 & $\mathrm{C}_{6} \mathrm{H}_{5} \mathrm{CHO}$ & $3 \mathbf{a}$ & 9 & 96 & $150-152^{35}$ \\
\hline 2 & 4- $\mathrm{CH}_{3} \mathrm{C}_{6} \mathrm{H}_{4} \mathrm{CHO}$ & $3 \mathbf{b}$ & 12 & 95 & $95-98^{35}$ \\
\hline 3 & $4-\mathrm{OCH}_{3} \mathrm{C}_{6} \mathrm{H}_{4} \mathrm{CHO}$ & $3 c$ & 10 & 95 & $187-189^{44}$ \\
\hline 4 & $4-\left(\mathrm{CH}_{3}\right)_{2} \mathrm{NC}_{6} \mathrm{H}_{4} \mathrm{CHO}$ & 3d & 13 & 90 & $211-214^{38}$ \\
\hline 5 & $4-\mathrm{OHC}_{6} \mathrm{H}_{4} \mathrm{CHO}$ & $3 \mathbf{e}$ & 12 & 92 & $124-126^{35}$ \\
\hline 6 & $4-\mathrm{NO}_{2} \mathrm{C}_{6} \mathrm{H}_{4} \mathrm{CHO}$ & 3f & 14 & 94 & $217-219^{35}$ \\
\hline 7 & $4-\mathrm{FC}_{6} \mathrm{H}_{4} \mathrm{CHO}$ & $3 g$ & 14 & 93 & $72-74^{38}$ \\
\hline 8 & 4- $\mathrm{ClC}_{6} \mathrm{H}_{4} \mathrm{CHO}$ & $3 \mathbf{h}$ & 14 & 92 & $77-79^{35}$ \\
\hline 9 & 4- $\mathrm{BrC}_{6} \mathrm{H}_{4} \mathrm{CHO}$ & $3 \mathbf{i}$ & 15 & 92 & $101-103^{44}$ \\
\hline 10 & $2-\mathrm{NO}_{2} \mathrm{C}_{6} \mathrm{H}_{4} \mathrm{CHO}$ & $\mathbf{3 j}$ & 15 & 92 & $215-218^{35}$ \\
\hline 11 & $\mathrm{C}_{6} \mathrm{H}_{5} \mathrm{CH}=\mathrm{CHCHO}$ & $3 \mathbf{k}$ & 14 & 94 & $98-100^{17}$ \\
\hline 12 & $2-\mathrm{OH}, 4-\mathrm{ClC}_{6} \mathrm{H}_{3} \mathrm{CHO}$ & 31 & 13 & 92 & $219-222^{14}$ \\
\hline 13 & 2-OH,5-OCH ${ }_{3} \mathrm{C}_{6} \mathrm{H}_{3} \mathrm{CHO}$ & $3 m$ & 12 & 90 & $112-115^{35}$ \\
\hline 14 & $4-\mathrm{CNC}_{6} \mathrm{H}_{4} \mathrm{CHO}$ & $3 n$ & 13 & 92 & $213-215^{14}$ \\
\hline 15 & $3-\mathrm{NC}_{5} \mathrm{H}_{4} \mathrm{CHO}$ & 30 & 12 & 85 & $138-140^{44}$ \\
\hline 16 & $2-\mathrm{SC}_{4} \mathrm{H}_{3} \mathrm{CHO}$ & $3 p$ & 14 & 80 & $148-150^{44}$ \\
\hline 17 & $2-\mathrm{OC}_{4} \mathrm{H}_{3} \mathrm{CHO}$ & $3 q$ & 13 & 82 & $325-329^{35}$ \\
\hline 18 & $\mathrm{CH}_{3} \mathrm{CHO}$ & $3 r$ & 15 & 80 & $149-151^{17}$ \\
\hline 19 & $\mathrm{CH}_{3} \mathrm{CH}=\mathrm{CHCHO}$ & $3 s$ & 14 & 78 & $124-128^{17}$ \\
\hline 20 & $\mathrm{C}_{6} \mathrm{H}_{11} \mathrm{CHO}$ & $3 t$ & 14 & 84 & $119-121^{35}$ \\
\hline 21 & $\mathrm{C}_{6} \mathrm{H}_{5} \mathrm{C}=\mathrm{OCH}_{3}$ & $\mathrm{NR}^{\mathrm{e}}$ & 35 & - & - \\
\hline 22 & $\mathrm{C}_{6} \mathrm{H}_{10} \mathrm{C}=\mathrm{O}$ & $\mathrm{NR}^{\mathrm{e}}$ & 35 & - & - \\
\hline
\end{tabular}

${ }^{a}$ All the products are characterized by spectral analysis.

${ }^{\mathrm{b}}$ Microwave irradiation.

${ }^{\mathrm{c}}$ Isolated yields.

${ }^{\mathrm{d}}$ Literature references.

${ }^{\mathrm{e}}$ No reaction.

In order to show the efficiency and generality of the present succinic acid catalyzed protocol, the results have been summarized in Table 4, comparing with the recently reported results in the literature. The protocol described in this study is comparatively better in terms of low cost, highly efficient, nontoxic, environmentally friendly readily available, organocatalyst and water as green solvent. Entries 8 and 10 (Table 4) are comparable with our catalyst efficacy, although, availability of the ionic liquids is less and expensive compared to the readily available cheap succinic acid. The reaction most probably proceeds initially activation of aldehyde by the catalyst to undergo electrophilic substitution reaction at C3 of indole and, after loss of water to produce azafulvenium salts. The formed azafulvenium salt then undergoes further addition with second indole molecule to afford bis(indolyl)methane derivatives. ${ }^{17,42}$ 
Table 4. Comparison of various organic acids $(10 \mathrm{~mol} \%)$ as catalyst on model reaction between indole (2 $\mathrm{mmol})$, benzaldehyde $(1 \mathrm{mmol})$ in water $(5 \mathrm{~mL})$ under microwave irradiation

\begin{tabular}{|c|c|c|c|c|}
\hline Entry & Reagent and conditions & Time (min) & Yield \% & References \\
\hline $\mathbf{1}$ & $\mathrm{LiClO}_{4}, \mathrm{MeCN}$, room temperature & 150 & 95 & 20 \\
\hline 2 & $\mathrm{MgSO}_{4}$, solvent free, $50{ }^{\circ} \mathrm{C}$ & 25 & 92 & 26 \\
\hline 3 & $\mathrm{P}_{2} \mathrm{O}_{5} / \mathrm{SiO}_{2}$, solvent free, room temperature & 30 & 94 & 31 \\
\hline 4 & 12-TPA, $\mathrm{H}_{3} \mathrm{PW}_{12} \mathrm{O}_{40}$, room temperature & 20 & 94 & 38 \\
\hline 5 & $\mathrm{BF}_{3} \cdot \mathrm{Et}_{2} \mathrm{O}$, room temperature & 120 & 90 & 41 \\
\hline 6 & Nano-SiO ${ }_{2}$, Ultrasonic irradiation & 60 & 93 & 32 \\
\hline 7 & $\mathrm{PPh}_{3} \cdot \mathrm{HClO}_{4}, \mathrm{CH}_{3} \mathrm{CN}$ & 30 & 61 & 36 \\
\hline 8 & [Bmim]Br, Microwave, $400 \mathrm{~W}$ & 8 & 95 & 33 \\
\hline 9 & Zeokarb-225, $\mathrm{CH}_{3} \mathrm{CN}$, room temperature & 450 & 95 & 34 \\
\hline 10 & {$\left[\mathrm{n}-\mathrm{Pr}_{2} \mathrm{NH}_{2}\right]\left[\mathrm{HSO}_{4}\right]$.IL/Microwave } & 5 & 95 & 35 \\
\hline 11 & Glycerin- $\mathrm{CeCl}_{3} \cdot 7 \mathrm{H}_{2} \mathrm{O}$, room temperature & 90 & 96 & 40 \\
\hline 12 & Tritylchloride, solvent free, room temperature & 20 & 90 & 43 \\
\hline 13 & Silica-gel, $100{ }^{\circ} \mathrm{C}$ & 60 & 99 & 39 \\
\hline 14 & $\mathrm{Ln}(\mathrm{OTf})_{3} / \mathrm{EtOH} . \mathrm{H}_{2} \mathrm{O}$ & 720 & 95 & 27 \\
\hline 15 & Succinic acid- $\mathrm{H}_{2} \mathrm{O}$, Microwave irradiation & 9 & 96 & Present work \\
\hline
\end{tabular}

\section{Conclusion}

In conclusion, a strategy using succinic acid in water under microwave irradiation has been developed for electrophilic substitution reactions of indoles with aldehydes giving bis(indolyl)metahnes in good to excellent yields (78-96\%). This procedure accomplished production of bis(indolyl)meythanes in conditions comparatively better in terms of low cost, high efficiency, nontoxicity, environmentally friendly readily available organocatalyst and water as green solvent. The present reaction condition is suitable for aldehydes only, providing chemoselectivity in the presence of ketones.

\section{References}

[1] Smith, A. L.; Stevenson, G. I.; Lewis, S.; Patel, S.; Castro, J. L. Solid-phase synthesis of 2,3-disubstituted indoles: discovery of a novel, high-affinity, selective h5-HT $\mathrm{HA}_{2 \mathrm{~A}}$ antagonist. Biorg. Med. Chem. Lett. 2000, 10, 2693-2696.

[2] Osawa, T.; Namiki, M. Struccture elucidation of streptindole, a novel genotoxic metabolite isolated from intestinal bacteria. Tetrahedron Lett. 1983, 24, 4719-4722.

[3] Karthik, M.; Tripathi, A. K.; Gupta, N. M.; Palanichamy, M.; Murugesan, V. Zeolite catalyzed electrophilic substitution reaction of indoles with aldehydes: synthesis of bis(indolyl)methaes. Cat. Commun. 2004, 5, 371375 .

[4] (a) Safe, S.; Papineni, S.; Chintharlapalli, S. Cancer chemotherapy with indole-3-carbinol, bis(3'indolyl)methane and synthetic analogs. Cancer Lett. 2008, 269, 326-338. (b) Chakrabarty, M.; Ghosh, N.; Basak, R.; Harigaya, Y. Dry reaction of indoles with carbonyl compounds on montmorillonite K10 clay: a mild, expedient synthesis of diindolylalkanes and vibrindole A. Tetrahedron Lett. 2002, 43, 4075-4078. 
[5] Bonnesen, C.; Eggleston, I. M.; Hayes, J. D. Diethyl indoles and isothiocyanates that are generated from Cruciferous vegetables can both stimulate apoptosis and confer protection against DNA damage in human colon cell lines. Cancer Res. 2001, 61, 6120-6130.

[6] Gong, Y.; Firestone, G. L.; Bjeldanes, L. F. 3,3'-Diindolyl methane is a novel topoisomerase II $\alpha$ catalytic inhibitor that induces S-phase retardation and mitotic delay in human hepatoma Hep G2 cells. Mol. Pharmacol. 2006, 69, 1320-1327.

[7] Bell, R.; Carmeli, S.; Sar, N. Vibrindole, a metabolite of the marine bacterium, vibrio parahaemolyticus, isolated from the toxic mucus of boxfish Ostracion cubicus. J. Nat. Prod. 1994, 57, 1587-1590.

[8] Kobayashi, M.; Aoki, S.; Gato, K.; Matsunami, K.; Kurosu, M.; Kitagawa, I. Marine natural products xxxiv. Trisindoline, a new anti-biotic indole trimer, produced by a bacterium of vibrio Sp separated from the marine sponge Hyrtios altum. Chem. Pharm. Bull. 1994, 42, 2449-2451.

[9] Sivaprasad, G.; Perumal, P. T.; Prabavathy, V. R.; Mathivanan, N. Synthesis and anti-microbial activity of pyrazolyl-bisindoles- Promising anti-fungal compounds. Bioorg. Med. Chem. Lett. 2006, 16, 6302-6305.

[10] Sujatha, K.; Perumal, P. T.; Muralidharan, D.; Rajendran, M. Synthesis, analgesic, and anti-inflammatory activities of bis(indolyl)methanes. Indian J. Chem. 2009, 48B, 267-272.

[11] Praveen, C.; DheenKumar, P.; Muralidharan, D.; Perumal, P. T. Synthesis, anti-microbial and anti-oxidant evaluation of quinolines and bis(indolyl)methanes. Bioorg. Med. Chem. Lett. 2010, 20, 7292-7296.

[12] Plimmer, J. R.; Gammon, D. W.; Ragsdale, N. N. Encyclopedia of Agrochemicals, Vol.3, John Wiley and Sons, New York, 2003.

[13] (a) He, X.; Hu, S.; Liu, K.; Guo, Y.; Xu, J.; Shao, S. Oxidized bis(indolyl)methane: A simple and efficient chromogenic-sensing molecule based on the proton transfer signaling mode. Org. Lett. 2006, 8, 333-336. (b) Martinez, R.; Espinosa, A.; Tarraga, A.; Molina, P. Bis(indolyl)methane derivatives as highly selective colourimetric and ratiometric fluorescent molecular chemosensors for $\mathrm{Cu}^{+2}$ cations. Tetrahedron 2008, 64, 2184-2191.

[14] Naidu, K. R. M.; Khalivulla, S. I.; Kumar, P. C. R.; Lasekan, O. $\mathrm{KHSO}_{4}-\mathrm{SiO}_{2}$ catalyzed facile synthesis of bis(indolyl)methanes. Org. Commun. 2012, 5, 150-159.

[15] Sharma, G. V. M.; Reddy, J. J.; Lakshmi, P. S.; Krishna, P. R. A versatile and practical synthesis of bis(indolyl)methanes/bis(indolyl)glycoconjugtes catalyzed by trichloro-1,3,5-triazine. Tetrahedron Lett. 2004, 45, 7729-7732.

[16] Firouzabadi, H.; Iranpoor, N.; Jafari, A. A. Aluminiumdodecatungstophosphate $\left(\mathrm{AlPW}_{12} \mathrm{O}_{40}\right)$, a versatile and a highly water tolerant green Lewis acid catalyzed efficient preparation of indole derivatives. J. Mol. Catal. A: Chem. 2005, 244, 168-172.

[17] Deb, M. L.; Bhuyan, P. J. An efficient and clean synthesis of bis(indolyl)methanes in a protic solvent at room temperature. Tetrahedron Lett. 2006, 47, 1441-1443.

[18] Zhang, Z. H.; Yin, L.; Wang, Y. M. An efficient and practical process for the synthesis of bis(indolyl)methanes catalyzed by zirconium tetrachloride. Synthesis 2005, 12, 1949-1954.

[19] Ji, S. J.; Wang, S. Y.; Zhang, Y.; Loh, T. P. Facile synthesis of bis(indolyl)methanes using catalytic amount of iodine at room temperature under solvent-free conditions. Tetrahedron 2004, 60, 2051-2055.

[20] Yadav, J. S.; Reddy, B. V. S.; Murthy, C. V. S. R.; Mahesh Kumar, G.; Madan, C. Lithium perchlorate catalyzed reactions of indoles: An expeditious synthesis of bis(indolyl)methanes. Synthesis 2001, 5, 783-787.

[21] Ji, S. J.; Zhou, M. F.; Gu, D. G.; Wang, S. Y.; Loh, T. P. Efficient synthesis of bis(indolyl)methanes catalyzed by Lewis acids in ionic liquids. Synlett. 2003, 13, 2077-2079.

[22] Mo, L. P.; Ma, Z. C.; Zhang, Z. H. CuBr 2 -catalyzed synthesis of bis(indolyl)methanes. Synth. Commun. 2005, $35,1997-2004$

[23] Xia, M.; Wang, S. H.; Yuan, W. B. Lewis acid catalyzed electrophilic substitution of indole with aldehydes and schiff's bases under microwave solvent free irradiation. Synth. Commun. 2004, 34, 3175-3182.

[24] Ramesh, C.; Banerjee, J.; Pal, R.; Das, B. Silica supported sodium hydrogen sulfate and amberlyst-15: Two efficient heterogeneous catalysts for facile synthesis of bis and tris( $1 H$-indol-3-yl)methanes from indoles and carbonyl compounds. Adv. Synth \& Catal. 2003, 345, 557-559.

[25] Pore, D. M.; Desai, U. V.; Thopate, T. S.; Wadgaonkar, P. P. A mild, expedient, solvent-less synthesis of bis(indolyl)alkanes using silica sulfuric acid as a reusable catalyst. Arkivoc 2006, xii, 75-80.

[26] Niknam, K.; Zolfigol, M. A.; Sadabadi, T.; Nejati, A. Preparation of indolyl methanes catalyzed by metal hydrogen sulfates. J. Iran. Chem. Soc. 2006, 3, 318-322.

[27] Chen, D.; Yu, L. B.; Wang, P. G. Lewis acid-catalyzed reactions in protic media: Lanthanide catalyzed reactions of indoles with aldehydes or ketones. Tetrahedron Lett. 1996, 37, 4467-4470.

[28] Zhang, L. P.; Li, Y. Q.; Zhou, M. Y. Efficient and eco-friendly process for the synthesis of bi(indolyl)methanes catalyzed by sodium hydrogensulfate monohydrate in ionic liquid n-butylpyridinium tetrafluoroborate. Chin. Chem. Lett. 2006, 17, 723-726. 
[29] Nasreen, A.; Varala, R.; Adapa, S. R. Copper nitrate trihydrate catalyzed efficient synthesis of bis(indolyl)methanes in acetonitrile at room temperature. J. Heterocycl. Chem. 2007, 44, 983-987.

[30] Koshima, H.; Matsusaka, W. N-bromosuccinimide catalyzed condensations of indoles with carbonyl compounds under solvent-free conditions. J. Heterocycl. Chem. 2002, 39, 1089-1091.

[31] Hasaninejad, A.; Zare, A.; Sharghi, H.; Niknam, K.; Shekouhy, M. $\mathrm{P}_{2} \mathrm{O}_{5} / \mathrm{SiO}_{2}$ as an efficient, mild and heterogeneous catalytic system for the condensation of indoles with carbonyl compounds under solvent-free conditions. Arkivoc 2007, xiv. 39-50.

[32] Ghodrati, K.; Hosseini, S. H.; Mosaedi, R.; Karami, C.; Maleki, F.; Farrokhi, A.; Hamidi, Z. Convenient, efficient, and green method for synthesis of bis(indolyl)methanes with nano- $\mathrm{SiO}_{2}$ under ultrasonic irradiation. Int. Nano. Lett. 2013, 3, 13.

[33] Zare, A.; Parhami, A.; Moosavi-Zare, A. R.; Hasaninejad, A.; Khalafi-Nezhad, A.; Beyzavi, M. H. A catalystfree protocol for the green and efficient condensation of indoles with aldehydes in ionic liquids. Can. J. Chem. 2009, 87, 416-421.

[34] Magesh, C. J.; Nagarajan, R.; Karthik, M.; Perumal, P. T. Synthesis and characterization of bis(indolyl)methanes, tris(indolyl)methaes, and new diindolylcarbazolyl methanes mediated by Zeokarb-225, a novel, recyclable, eco-benign heterogeneous catalyst. Appl. Catal. A: 2004, 266, 1-10.

[35] Das, P. J.; Das, J. Synthesis of aryl/alkyl (2,2'-bis-3-methylindolyl)methanes and aryl(3,3'-bisindolyl)methanes promoted by secondary amine based ionic liquids and microwave irradiation. Tetrahedron Lett. 2012, 53, 4718-4720.

[36] Nagarajan, R.; Perumal, P. T. Electrophilic substitution of indoles catalyzed by triphenyl phosphonium perchlorate: Synthesis of 3 -acetyl indoles and bisindolyl methane derivatives. Synth. Commun. 2002, 32, 105109.

[37] Kokare, N. D.; Sangshetti, J. N.; Shinde, D. B. Oxalic acid as a catalyst for efficient synthesis of bis(indolyl)methanes and 14-aryl-14H-dibenzo[a,j]xanthenes in water. Chin. Chem. Lett. 2008, 19, 1186-1189.

[38] Giri, B. Y.; Prabhavathidevi, B. L. A.; Vijayalakshmi, K.; Prasad, R. B. N.; Lingaiah, N.; Prasad, P. S. S. A mild and efficient synthesis of bis(indolyl)methane derivatives catalyzed by monoammonium salt of 12 tungstophosphoric acid. Indian J. Chem. 2012, 51, 1731-1737.

[39] Mendes, S. R.; Thurow, S.; Fortes, M. P.; Penteado, F.; Lenardão, E. J. B. Alves, D.; Perin, G.; Jacob, R. G. Synthesis of bis(indolyl)methanes using silica gel as an efficient and recyclable surface. Tetrahedron Lett. 2012, 53, 5402-5406.

[40] Silveira, C. C.; Mendes, S. R.; Libero, F. M.; Lenardão, E. J. Perin, G. Glycerin and $\mathrm{CeCl}_{3} .7 \mathrm{H}_{2} \mathrm{O}$ : a new and efficient recyclable medium for the synthesis of bis(indolyl)methanes. Tetrahedron Lett. 2009, 50, 6060-6063.

[41] Xu, X. F.; Xiong, Y.; Ling, X. G.; Xie, X. M.; Yuan, J.; Zhang, S. T.; Song, Z. R. A practical synthesis of bis(indolyl)methanes catalyzed by $\mathrm{BF}_{3} \cdot \mathrm{Et}_{2} \mathrm{O}$. Chin. Chem. Lett. 2014, 25, 406-410.

[42] Seyedi, N. An efficient green procedure for the synthesis of bis(indolyl)methanes in water. J. Sci. I. R. Iran. 2013, 24, 205-208.

[43] Nezhad, K.; Parhami, A.; Zare, A.; Moosavi-Zare, A. R.; Hasaninejad, A.; Panahi, F. Trityl chloride as a novel and efficient organic catalyst for room temperature preparation of bis(indolyl)methanes under solvent-free conditions in neutral media. Synthesis 2008, 617-621.

[44] Handy, S.; Westbrook, N. M. A mild synthesis of bis(indolyl)methanes using a deep eutectic solvent. Tetrahedron Lett. 2014, 55, 4969-4971.

[45] (a) Khajuria, R.; Saini, Y.; Kapoor, K. K. A solvent-free synthesis of ethyl 3,5-diaryl-1H-pyrrole-2carboxylates via triethyl phosphate mediated reductive cyclization of ethyl 2-nitro-5-oxo-3,5-diarylpentanoates under microwave irradiation. Tetrahedron Lett. 2013, 54, 5699-5702. (b) Beldar, A. G.; Sharma, M. Eur. J. Chem. 2011, 8, 288-292. (c) Abbasa, E. M. H.; Gomha, S. M.; Farghaly, T. A. Multi component reactions for synthesis of bioactive polyheterocyclic ring systems under controlled microwave irradiation. Arab. J. Chem. 2014, 7, 623-629. (d) Abd El-Rahman, N. M.; El-kateb, A. A.; Mady, M. F. Simplified approach to the uncatalyzed Knoevenagel condensation and Michael addition reactions in water using microwave irradiation. Synth. Commun. 2007, 37, 3961-3970. (e) Wang, P.; Ma, C.; Chen, S.; Zhu, S.; Lou, Z.; Wang, H. Conversion of steroid saponins into diosgenin by catalytic hydrolysis using acid-functionalized ionic liquid under microwave irradiation. J. Clean. Prod. 2014, 79, 265-270. (f) Madhvi, A. S.; Jauhari, S.; Desai, K. R. A brief review: Microwave assisted organic reactions. Arch. Appl. Sci. Res. 2012, 4, 645-661.

[46] (a) Hazeri, N.; Maghsoodlou, M. T.; Khorassani, S. M. H.; Aboonajmi, J.; Safarzaei, M. A green protocol for one-pot three-component synthesis of amidoalkyl naphthols catalyzed by succinic acid. Chem. Sci. Trans. 2013, 2, 330-336. (b) Hazeri, N.; Maghsoodlou, M. T.; Khorassani, S. M. H.; Aboonajmi, J.; Lashkari, M.; Sajadikhah, S. S. A green protocol for one-pot three-component synthesis of $\alpha$-amino phosphonates catalyzed by succinic acid. Res. Chem. Intermed. 2014, 40, 1781-1788. (c) Zeikus, J. G.; Jain, M. K.; Elankovan, P. Biotechnology of succinic acid production and markets for derived industrial products. Appl. Microbiol. 
Biotechnol. 1999, 51, 545-552. (d) Vermuri, G. N.; Eiteman, M. A.; Altman, E. Effects of growth mode and pyruvate carboxylase on succinic acid production by metabolically engineered strains of Escherichia coli. Appl. Environ. Microbiol. 2002, 68, 1715-1727. (e) Lee, P. C.; Lee, W. G.; Kwon, S.; Lee, S. Y.; Chang, H. N. Batch and continuous cultivation of Anaerobiospirillum succiniciproducens for the production of succinic acid from Whey. Appl. Microbiol. Biotechnol. 2000, 54, 23-27. (f) Wan, C.; Li, Y.; Shahbazi, A.; Xiu, S. Succinic acid production from cheese Whey using Actinobacillus succinogenes 130-Z. Appl. Biochem. Biotechnol. 2008, 145, 111-119. (g) Patil, S.; Pawar, P. B.; Jadhav, S. D.; Deshmukh, M. B. An efficient one-pot multicomponent synthesis of dihydropyridines by using succinic acid as mild organocatalyst. Asian J. Chem. 2013, 25, 9442-9446.

[47] (a) Nasreen, A. L-Proline catalyzed one pot synthesis of $\alpha$-amino nitriles. Tetrahedron Lett. 2013, 54, 37973800. (b) Nasreen, A. Cupric nitrate catalyzed efficient and facile synthesis of 1,8-dioxo-octahydroxanthene derivatives. Asian J. Chem. 2013, 25, 7535-7538. (c) Nasreen, A.; Borik, M. R. Cobalt(II) chloride catalyzed one-pot synthesis of 2-substituent and 3-substituent-4(3H)-quinazolinones. Orien. J. Chem. 2014, 30, $761-768$. (d) Nasreen, A.; Adapa, S. R. Ferrous sulfate promoted conversion of $N, N$-dimethylhydrazones and phenylhydrazones to carbonyl compounds. Org. Prep. Proc. Int. 1999, 31, 573-575. (e) Varala, R.; Nasreen, A.; Ramu, E.; Adapa, S. R. L-Proline catalyzed selective synthesis of 2-aryl-1-ethyl-1H-benzimidazoles. Tetrahedron Lett. 2007, 48, 69-72.

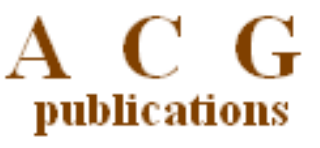

(C) 2017 ACG Publications. 